\title{
The Impact of E-Integrated Marketing Communication (E-IMC) on Brand Equity for New College
}

\author{
Fardiansyah ${ }^{\text {a.* }}$, Mahruza ${ }^{\text {a. }}$, Salya Rater ${ }^{\text {a. }}$, DS Putra ${ }^{\text {a. }}$, Asmaidi ${ }^{\text {a.. }}$ \\ ${ }^{a}$ Polytechnic of South Aceh, Merdeka Street, Komplek Reklamasi Pantai, Tapaktuan city, 23751, Indonesia \\ *fardian.poltas@gmail.com
}

ARTICLE INFO

Article history:

Accepted

Keywords:

IMC

E-IMC

Marketing Communication

Brand-New Polytechnic

Qualitative Methods

\section{ABSTRACT}

This research discusses the impact of the application of E-Integrated Marketing Communication (E-IMC) applied to new universities. This qualitative research refers to the theoretical reference written by John W. Creswell. The sample was determined using the snowball sampling technique and the data collection technique was carried out by in-depth interviews (in-depth interview) and documentation. This study aims to describe the impact of the application of integrated marketing communications applied by polytechnic universities. The findings indicate that user experience affects the E-IMC typology used. E-IMC effects brand equity in higher education. Further research can avail a research model and test the model with quantitative studies with the addition of demographic factors. Because the object of this research is a new polytechnic type of university, the different types of tertiary institutions can also be an additional variable to be studied further.

Copyright (C) 2021 Politeknik Aceh Selatan. All rights reserved.

\section{Introduction}

The South Aceh Polytechnic (POLTAS) tends to expense on promotions to attract prospective students. This is done by utilizing advertisements in newspapers, billboards, and other media such as public relations and direct promotion to those future students. However, it did not make a significant contribution to attain an increase in the next year's enrollment. Furthermore, brand-new campus recognition in public is essential to the success of this organization. When customers and consumers become aware of a new product or new brand, they tend to approach and try out the new offering [1].

Tight competition between public and private universities in attracting prospective students becomes immense. Based on information taken from [2], it shows that there are 156 tertiary institutions in Aceh consisting of 60 academies, 6 polytechnics, 84 colleges, 5 institutes, 16 universities, and 1 community academy, thus triggering a competition between universities. In terms of quality, this competitive situation has prompted these tertiary institutions to improve themselves in managing their educational institutions.

In the era of the industrial revolution 4.0, information technology has encouraged the development of marketing discipline and concepts, one of which is making internet services an option in communicating to stakeholders. Based on data released by [3], it is stated that internet users from 15-19 years of age have the highest penetration (reaching 91\%) and those aged 20-24 years reached $85.5 \%$ of the total 171.17 million internet users in Indonesia in 2018.

Marketing activities will not take place if there is no communication. Communication can help producers offer their products and influence consumers. The process of integrating these marketing communication elements is known as Integrated Marketing Communication (IMC). The 
most significant structural barriers to traditional IMC implementation are minimal budget and lack of database technology, increased market and mass media fragmentation, a saturation of traditional media channels, new iterative marketing concepts such as the focus of relationship marketing, in addition to the use of internet acquisition of more control and power over the communication process. due to the prevalence of the internet and recent advances in information technology [4].

E-Integrated Marketing Communication (E-IMC) is a relatively new communication discipline defined as a separate line from the communication discipline. Jensen and Jepsen [5] offer a new typology for E-IMC. A proposed four-discipline model includes fifteen sub-tools that are inferred from the main research work studied. The four E-IMC disciplines are online advertising, online Public Relations (PR), online sales promotion, and online communication links. E-IMC includes marketing campaigns on the internet and mobile which include marketing activities such as e-mail, blogs, websites, podcasts, internet tv, and mobile-based communications such as SMS, MMS, WAP, and GPRS based applications [6]. Alexandru and Carmen [7] stated that online communication tools are classified depending on the purpose of whether to attract or retain customers.

In this study, the researcher intends to analyze the application of E-IMC in New Tertiary Education Institutions by using a phenomenological qualitative methodology approach to describe the effect of E-IMC on the interests of prospective students. This study is expected to explore new factors in proposing a conceptual research model.

\section{Theorical Review}

\subsection{Brand Equity}

The American marketing association defines a brand as a name, sign, symbol, design, or a combination of these, which is intended to identify the goods or services of a seller or group of sellers and distinguish them from competitors' goods and services. A brand represents a set of shared values. and is communicated by marketers, senior company officials, and employees consistently over the long term.

Brand equity is the added value provided to products and services [8]. This value can be reflected in the way consumers think, feel, and act on the company's brand, price, market share, and profitability. The concept of brand equity can be considered, both from the perspective of the organization that owns the brand and from the perspective of the customer [9].

Brand awareness is a basic dimension of brand equity [9]. From the point of view of an individual consumer, a brand does not have brand equity unless the consumer is at least aware of the brand's existence. Achieving brand awareness is an initial challenge for new brands. Maintaining a level of brand awareness is a task that existing brands must face. 


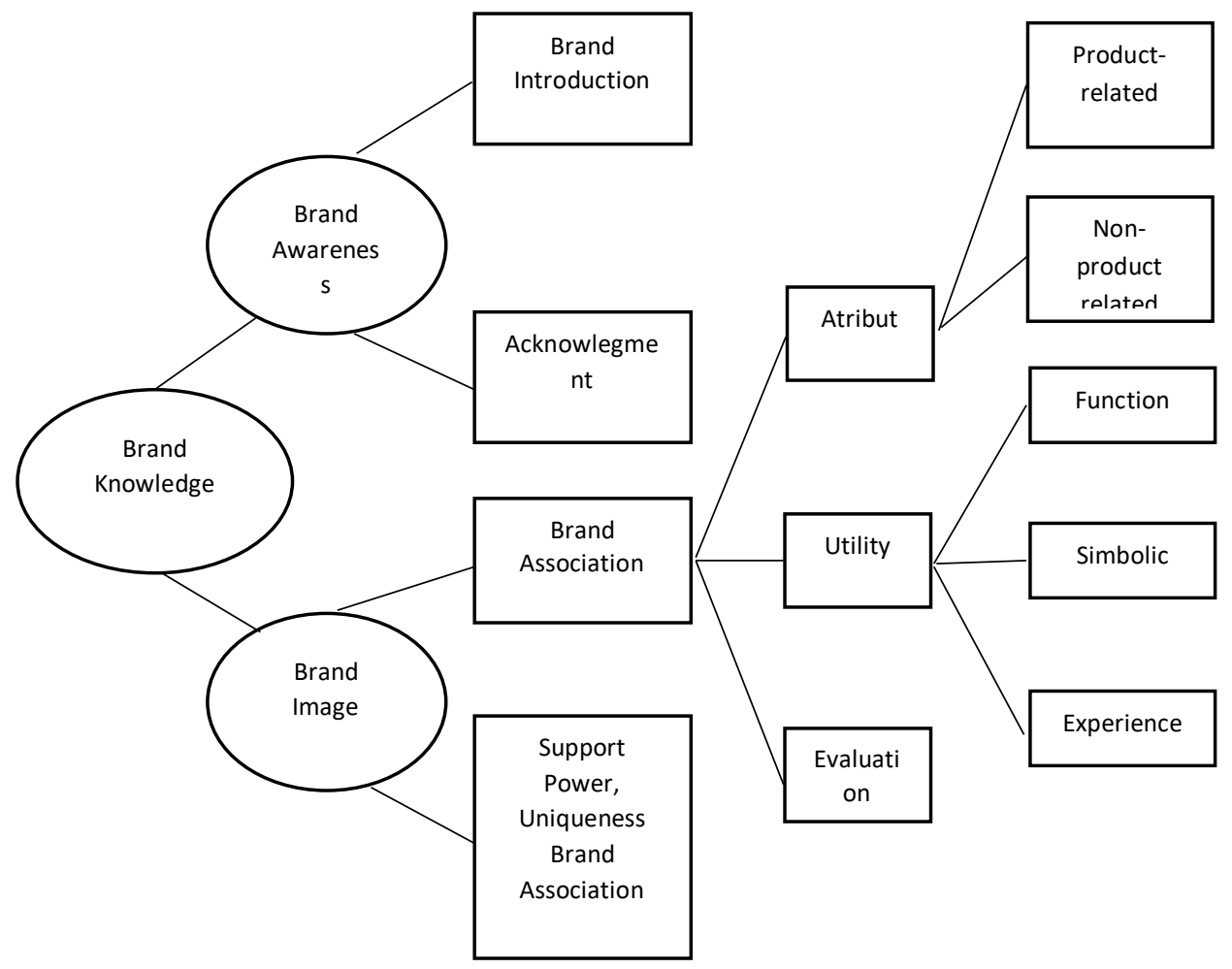

Consumer Based Brand Equity Framework [10].

\subsection{E-Integrated Marketing Communication (E-IMC)}

Integrated Marketing Communication (IMC) experts provide slightly different points of view regarding this management practitioner, and not all practitioners agree on the definition of IMC. The concept developed in the 1980s is defined by Schultz [11] as a strategy in business processes by planning, building, executing, and evaluating the implementation of a coordinated brand communication program for consumers, customers, or other targets relevant to external and internal audiences. Meanwhile, the American advertising agency association The American Association of Advertising Agency says that IMC is a mature marketing communication planning concept by evaluating the role of each form of marketing communication (general advertising, sales promotion, public relations, and others) and integrating the forms of communication. marketing is to provide clarity, consistency, and maximum communication impact [12].

Electronic Integrated Marketing Communication (E-IMC) is a marketing approach that utilizes internet-based media for marketing communication activities to target segments. This activity creates a new channel called online marketing, this marketing communication is separate on the internet. Jensen and Jepsen [5] offer a new typology for E-IMC. A proposed four-discipline model includes fifteen sub-tools that are inferred from the main research work studied. The four EIMC disciplines are online advertising, online Public Relations (PR), online sales promotion, and online communication links. E-IMC includes marketing campaigns on the internet and mobile which include marketing activities such as e-mail, blogs, websites, podcasts, internet tv, and mobile-based communications such as SMS, MMS, WAP, and GPRS based applications [6].

\section{Method}

At this stage, issue identification is carried out to obtain information on the chosen research topic which aims to find problems from the E-IMC phenomenon that occurs in Polytechnic-type universities. Literature studies are carried out by collecting supporting data on theories that support 
research, research. related, as well as the methods that are widely used as a reference in this study. Understanding of the literature aims to formulate a theoretical basis related to conducting this research. This literature can help researchers from problem formulation to designing research models.

This is a qualitative research with an information systems study perspective. The reason for using a qualitative approach is because researchers intend to understand the social situation indepth, find patterns, and explore broader implications of the E-IMC phenomenon that occurs in Indonesia. In this approach, the researcher creates a complex picture, examines words, reports in detail from the views of the respondent, and conducts studies on natural situations. This qualitative research design refers to the theoretical reference written [13].

Table 1. Informan Criteria

\begin{tabular}{llll}
\hline Criteria & Age & Work Length & Information \\
\hline Informant I & 38 y.o & $10 \mathrm{y}$ & $\begin{array}{l}\text { Selected based on his track record as Deputy } \\
\text { Director 1. The informant is the person who is } \\
\text { responsible for marketing management at the } \\
\end{array}$ \\
& & Polytechnic of South Aceh. \\
\hline Informant II & 25 y.o & $7 \mathrm{y}$ & $\begin{array}{l}\text { Selected based on the recommendation of the } \\
\text { Deputy Director 1 of the South Aceh Polytechnic as } \\
\text { a Head of Public Relations (PR) who is responsible } \\
\text { for target orientation (marketing, branding, client } \\
\text { maintenance) }\end{array}$ \\
\hline
\end{tabular}

\section{Results and Discussion}

We present the analysis findings in terms of two findings. The findings and explanations of the results of the research that have been carried out found as many as 2 (two) findings, each of which can be explained as follows:

\section{Finding 1 - User experience influences the E-IMC typology.}

Based on the results of interviews and observations conducted by researchers, it is known that good user experience attracts students and retains students has an influence on each of the EIMC typologies, namely, online advertising, online public relations, online sales promotion, online relationship communications. Each of these dimensions (attracting students and retaining students) builds on experiences that indirectly shape student targets, which create different student segments. The use of marketing communication tools varies from segment to segment.

\section{Finding 2 - E-IMC typology affects Brand Equity.}

A strong brand will influence the strength of the product. As an effort to keep students loyal is to make a differentiation that will differentiate another brand from the same product. Every university wants its brands to have high brand equity. Electronic-Integrated Marketing Communication (E-IMC) integrates and coordinates various Higher Education communication channels to deliver clear, consistent, and attractive messages about the organization and its products. E-IMC can contribute to brand equity by embedding the brand in memory and creating a 
brand image. Different student segments influence the online marketing communication tools used by the College. Therefore, it can be concluded that E-IMC typology affects Brand Equity

In this study, we propose two research questions. The first research question was used to see the user's perspective about the experience using E-IMC and how it affects the typology used. The second research question seeks to understand the application of the E-IMC typology and how it affects brand equity.

Based on the description above, the results of research and interviews have proposed a conceptual model that is proposed based on theoretical studies and findings. Where the user experience (attracting and retaining students) of New Higher Education affects the E-IMC typology (online advertising, online public relations, online sales promotion, online relationship communications). E-IMC typology affects brand equity (Brand Awareness, Brand Image). The following is the final model of the research:

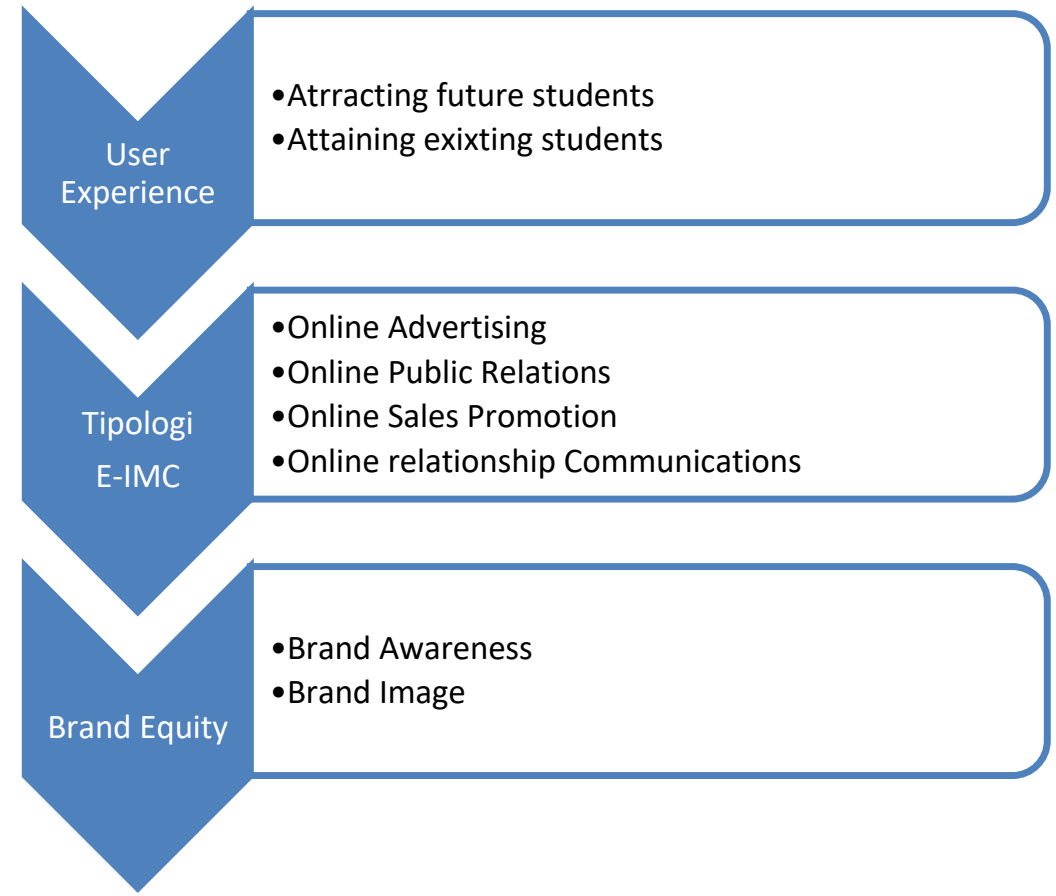

Figure 2. Proposed Conceptual Model

While other findings, which become additional notes in this study are:

1. The use of E-IMC is useful for improving the communication relationship between prospective students and the New Higher Education in a two-way interactive communication process. This supports the research conducted by Valos, Ewing, and Powell [14].

2. In addition to higher education communication with prospective students, E-IMC can improve interactive communication between students. This is evidenced by the existence of an online student community forum in each Study Program. This supports the research conducted by Owen and Humphrey [15].

3. College Marketers recognize the popularity of online marketing tools, some online marketing tools are known only by definition and are not used in practice. This supports the research conducted by Alexandru and Carmen [7].

4. Limited funding for new bodies affects the implementation of E-IMC. This finding is consistent with research conducted by Valos et al. [14], Fang et al. [4]. 


\section{Conclusion}

This research is qualitative research with a phenomenological approach. The explanation of phenomenological studies describes the general meaning of several individuals to various life experiences related to concepts or phenomena [13]. The main purpose of phenomenological research is to reduce individual experiences of certain phenomena and become descriptions of the essence or universal essence.

Higher education can take advantage of E-IMC as a business opportunity and can determine the type of online marketing media that fits the target or market share. Practical contributions from this research provide an overview of E-IMC implementation at this educational body to maintain its survival and development.

Due to the limited number of samples taken, this study cannot be generalized. Future research can develop a research model and test the model with quantitative studies. Because the object of this research is a new type of Polytechnic Tertiary Education Institution, the different types of Higher Education can also be an additional variable to be further studied.

\section{References}

[1] Seteenkamp, J.E.M. dan Gielens, K. (2003), Consumer and Market Drivers of the Trial Probability of New Consumer Packaged Goods, Journal of Consumer Research, Vol 30, p. 368.

[2] Pangkalan Data Pendidikan Tinggi (PDPT) KEMENRISTEK DIKTI https://forlap.ristekdikti.go.id/perguruantinggi/homegraphpt (accessed on 10 August 2019).

[3] Asosiasi Pengguna Jasa Internet Indonesia (APJII). 2018. Indonesia Internet Users. Laporan Asosiasi Penyelenggara Jasa Internet Indonesia. (accessed on 10 August 2019).

[4] Fang, Y., Qureshi, I., Sun, H. and McCole, P. 2014. Trust, Satisfaction, and Online Repurchase Intention: The Moderating Role of Perceived Effectiveness of E-Commerce Institutional Mechanism. MIS Quarterly, 38, 407-427.

[5] Jensen, M.B. and Jepsen, A.L. 2006. Online Marketing Communications: Need for a New Typology for IMC? Journal of Website Promotion, 2, 19-35.

[6] Chauhan, K. 2014. Organizational Flexibility and Competitiveness: Assessment of Electronicbased Integrated Marketing Communication for Rural Areas in North India, 14, 197-211.

[7] Alexandru, P.N. and Carmen, A. 2011. A Qualitative Research Regarding the Marketing Communication Tools Used in the Online Environment. Annals of the University of Oradea, Economic Science Series, 119-125.

[8] Kotler, Philip dan Kevin L. Keller. 2016. Manajemen Pemasaran edisi 12. Jakarta: Indeks

[9] Shimp, T.A. 2014. Komunikasi Pemasaran Terpadu Dalam Periklanan dan Promosi Edisi 8. Jakarta : Penerbit Salemba Empat.

[10] Keller, L.L. 1993. Conceptualizing, measuring, and managing customer-based brand equity. Journal of Marketing. (57) 1:1-22.

[11] Schultz, D.E. and Schultz, H.F. (2004), IMC the next generation: five steps for delivering value and measuring returns using marketing communication, McGraw-Hill.

[12] Belch, George E., Belch, Michael A. 2009. Advertising and Promotion: An Integrated Marketing Communication Perspective. 8th Edition. New York: McGraw-Hill

[13] Creswell, J. W. 2015. Penelitian Kualitatif dan Desain Riset Terjemahan Indonesia. Yogyakarta: Pustaka Pelajar.

[14] Valos, M. J., Ewing, M.T. and Powell, I. H. (2010) Practitioner Prognostications on the Future of Online Marketing. Journal of Marketing Management, 26, 361-376. 
[15] Owen, R. and Humphrey, P. (2009) The Structure of Online Marketing Communication Channels. Journal of Management and Marketing Research, 2, 54-62 